\title{
Sucralfate in the treatment and prevention of gastric ulcer: multicentre double blind placebo controlled study
}

\begin{abstract}
A L Blum, H Bethge, J Ch Bode, W Domschke, G Feurle, K Hackenberg, B Hammer, W Hüttemann, M Jung, G Kachel, H Kaess, B C Manegold, P Peter, T Pfleiderer, H G Rohner, U Rasenack, R Sanwald, G A Stalder, J-J Vallotton
\end{abstract}

\begin{abstract}
A randomised controlled multicentre trial was performed in 160 patients with gastric ulcer, proved by endoscopy and biopsy, to compare ulcer healing with sucralfate and ranitidine (double blind double dummy design) and to assess the effect of maintenance treatment with sucralfate on ulcer recurrence (double blind placebo controlled design). The healing rates were similar with $4 \mathrm{~g}$ sucralfate suspension per day and $300 \mathrm{mg}$ ranitidine per day $(82 \%$ and $88 \%$ after 12 weeks, respectively). Of the 109 patients with healed ulcers, 92 were entered into the maintenance trial and treated with sucralfate tablets ( $2 \mathrm{~g}$ per day) or placebo tablets. Maintenance treatment with sucralfate delayed symptoms of gastric ulcer recurrence. Lifetable analysis showed significant differences between sucralfate and placebo, both after six months $(p=0.018)$ and after 12 months $(p=0.044)$. The rates of symptom recurrences were $13 \%$ and $34 \%$ after six months and $34 \%$ and $55 \%$ after 12 months for sucralfate and placebo, respectively. The rate of asymptomatic recurrences after 12 months was similar in the two groups $(9 \%$ and $10 \%$, respectively). The recurrence rate was higher in patients who had never taken non-steroidal anti-inflammatory drugs than in those who had but had stopped on admission to the study. It was also higher in patients with recurrent ulcer and in those with scarring deformation and narrowing of the pylorus. Maintenance treatment with sucralfate slowed the appearance of symptom recurrences of gastric ulcer.
\end{abstract}

The prevention of gastric ulcer recurrences is still a major problem. While it is possible to delay the recurrence of a duodenal ulcer by initial treatment with agents such as bismuth compounds,' this is not the case for gastric ulcer. ${ }^{2-8}$ Maintenance treatment in patients with healed gastric ulcers has been attempted with varying success using cimetidine, ${ }^{9-21}$ ranitidine, ${ }^{1222-28}$ pirenzepine, ${ }^{29}$ carbenoxolone, ${ }^{3031}$ Caved-S, ${ }^{3}$ antacids, ${ }^{1931}$ and also sucralfate. ${ }^{42032-35}$

The results of randomised maintenance trials comparing sucralfate with either placebo ${ }^{32-35}$ or cimetidine ${ }^{2033}$ are not conclusive for the following reasons: a small number of patients admitted to the trial,,$^{33}$ a short duration of only six months, ${ }^{+323435}$ failure to standardise initial ulcer treatment, ${ }^{20}{ }^{33-35}$ administration of different doses of sucralfate during maintenance treatment, ${ }^{40232-35}$ problems with randomisation and blinding, ${ }^{4}$ and inclusion of patients with pyloric ulcers in the gastric ulcer group. ${ }^{20}$ Some groups of patients appear in more than one publication $^{3336}$ but are often quoted as belonging to different studies. Information on 497 patients with gastric ulcer is available from these trials. ${ }^{42032-35}$ The four placebo controlled trials lasting for six months gave widely differing results; the overall recurrence rate was lower with sucralfate $(26 / 101,26 \%)$ than with placebo $(50 / 91,55 \%)$. No information on the one year recurrence rate is available. Thus, the value of sucralfate in the longterm maintenance treatment of gastric ulcer patients remains to be established.

We therefore planned an adequately sized, double blind one year trial where only patients with an endoscopically proved healed gastric ulcer were included and both initial ulcer treatment and maintenance treatment were predefined by randomisation before admission to the initial treatment phase.

\section{Patients and methods}

The patients entered into this study fulfilled the following criteria. They were ambulatory, had a benign gastric ulcer proved by endoscopy and biopsy, were over 18 years of age, gave informed consent, were likely to cooperate, and were willing to fill in a diary card.

At the onset of the study the gastric ulcer had a diameter of 5 to $30 \mathrm{~mm}$ (ulcer size was estimated with open biopsy forceps; for calculation of ulcer area see Blum et $a l^{37}$ ), was located entirely in the stomach without involving the pyloric area or the duodenal bulb, showed no endoscopical signs of acute ulceration (large, flat, irregular, multiple mucosal defects), and had not bled within the previous 24 hours. At least two biopsy specimens from the ulcer area, four from the ulcer wall, and two from the surrounding mucosa showed no malignant tissue or severe dysplasia. The presence of a deep ulcer with edges markedly de Gastro-entérologie, CHUV, CH-1011 Lausanne,

Accepted for publication 11 September 1989 
raised above the general mucosal surface was recorded. An antrum with standing folds, not flattened by forceful insufflation of air, was considered to show scarring deformation. Pyloric deformation was diagnosed when the open pylorus was neither round nor oval. 'Stressful life events' were recorded when the patients responded affirmatively to the question: Do you think that your present ulcer attack is the consequence of stressful life events? Daily use of coffee, cigarettes, non-steroidal antiinflammatory drugs, and alcohol was recorded.

Patients with reflux oesophagitis or a pyloric or duodenal ulcer were excluded from this study. Other exclusion criteria were age below 18 years, pretreatment with antiulcer drugs, surgery in the upper gastrointestinal tract (except for appendectomy and surgery for inguinal hernia), continuing treatment with non-steroidal antiinflammatory drugs or other potentially ulcerogenic drugs, alcoholism (daily pure ethanol consumption of more than $100 \mathrm{ml}$ (women) or more than $120 \mathrm{ml}$ (men), or behaviour compatible with alcoholism), and concurrent diseases which might have influenced longterm outcome such as malignancy, liver cirrhosis, or renal insufficiency. Pregnant and lactating women were also excluded.

The study was accepted by the Ethics Committee of the Triemli Hospital.

\section{INITIAL ULCER TREATMENT}

Initial ulcer treatment has been described in detail elsewhere. ${ }^{37}$ Briefly, endoscopy was performed before the patient was entered into the trial. Initial curative treatment was started within 24 hours after endoscopy. The first control endoscopy was performed six weeks after treatment was started. When the ulcer was healed four biopsy specimens from the ulcer scar and two specimens from the surrounding mucosa were taken. Healing was defined as an endoscopical appearance compatible with complete re-epithelialisation and the absence of mucosal defects in the biopsy specimens. Patients with malignancy or severe dysplasia in any of the biopsy specimens were excluded from the maintenance trial. Patients whose ulcer had not healed after six weeks were treated for another six weeks and endoscopy was repeated after a total treatment of 12 weeks.

\section{MAINTENANCE TREATMENT}

All patients whose ulcer had healed within 12 weeks were eligible for the maintenance part of the study. Complete informed consent was again given at the start of maintenance treatment. Patients were introduced into the maintenance study only if they did not take potentially ulcerogenic drugs. All patients who had previously taken non-steroidal anti-inflammatory drugs stopped taking them when the gastric ulcer was diagnosed. No suggestions about diet were made. The patients were informed that smoking was potentially harmful and might provoke ulcer recurrence; despite this, none of the smokers changed their smoking habits. The patients were allowed to take alcoholic beverages with their meals and were advised not to take hard liquor on an empty stomach.

Maintenance treatment was started immediately after endoscopy. Outpatient visits were scheduled at two monthly intervals. During these visits weight and blood pressure were measured and the patients were interviewed concerning symptoms suggestive of a recurrence. When a recurrence was suspected endoscopy was performed. When no recurrence was suspected the patient received drugs for the next two months and a new outpatient appointment was made. In the event of epigastric distress occurring between scheduled visits, the patients were asked to contact their physician; an interim, off-schedule endoscopy was performed even if only mild or atypical symptoms were present. At the end of the one year maintenance period an endoscopy was performed on all patients who were still in the trial.

\section{MEDICATION}

The patients were randomly assigned to one of the following four treatment arms: (i) initial ulcer treatment with sucralfate followed by maintenance treatment with sucralfate; (ii) sucralfate followed by placebo; (iii) ranitidine followed by sucralfate; (iv) ranitidine followed by placebo. For each patient a complete set of medication for both phases of the study was available on admission.

Sucralfate was given for initial ulcer treatment as a suspension contained in plastic bags $(5 \mathrm{ml}$ of the suspension corresponded to $1 \mathrm{~g}$ of sucralfate) and as tablets ( $1 \mathrm{~g}$ each) in the maintenance phase. For initial ulcer treatment patients took $5 \mathrm{ml}$ of the sucralfate suspension four times daily plus a ranitidine placebo, one tablet twice daily; those allocated to ranitidine treatment took one tablet $(150 \mathrm{mg})$ twice daily plus a placebo sucralfate suspension $(5 \mathrm{ml})$ four times daily. In this double dummy system sucralfate suspension and placebo suspension were identical in appearance, colour, and taste. The same was true for ranitidine tablets and placebo tablets. The suspension was taken a half hour before breakfast, lunch, and dinner and before going to bed. The tablets were taken together with the suspension before breakfast and before going to bed. The patients had free access to chewable tablets containing an antacid with a very low buffer capacity ( $3 \mathrm{mmol} /$ tablet).

In the double blind maintenance treatment trial the patients who were randomised to treatment with sucralfate took a tablet containing $1 \mathrm{~g}$

TABLE I Patients' characteristics

\begin{tabular}{llll}
\hline & \multicolumn{3}{l}{ Maintenance treatment } \\
\cline { 2 - 4 } Characteristics & Sucralfate & Placebo & Total \\
\hline Patients (n) & 49 & 42 & 91 \\
Men/women (n) & $27 / 22$ & $24 / 18$ & $51 / 40$ \\
$\begin{array}{l}\text { Age (years)(mean, range) } \\
\text { Location of the ulcer: }\end{array}$ & $55(35-83)$ & $56(26-83)$ & $56(26-83)$ \\
$\quad \begin{array}{l}\text { Corpus-antrum } \\
\text { Initial ulcer treatment with: }\end{array} \quad 16-33$ & $12-30$ & $28-36$ \\
$\quad \begin{array}{l}\text { Ranitidine } \\
\quad \text { Sucralfate }\end{array}$ & 27 & 24 & 51 \\
$\begin{array}{c}\text { Time to ulcer healing: } \\
\quad \text { Complete after 6 weeks }\end{array}$ & 22 & 17 & 40 \\
$\quad$ Complete after 12 weeks & 11 & 32 & 70 \\
\hline
\end{tabular}


of sucralfate half an hour before breakfast and a second tablet in the evening before retiring. The patients who were randomised to placebo took placebo tablets which were identical to sucralfate tablets in appearance, taste, and colour. During the maintenance trial no antacid tablets were given.

\section{INVESTIGATORS}

The investigators in this study had collaborated in at least two previous studies on gastric ulcer and had already established standardised endoscopical criteria for the diagnosis of benign gastric ulcer and ulcer healing. ${ }^{38}$

\section{AIM OF THE STUDY - STATISTICAL ANALYSIS}

The statistical methods applied to initial ulcer treatment have been described previously. ${ }^{37}$ The study was designed to detect a difference in the healing rates between two curative treatments of at least $25 \%$ with an $80 \%$ probability and a level of alpha $=5 \%$. On this basis, at least 150 patients had to be entered for the initial ulcer treatment stage. It was estimated that approximately half of the patients thus admitted would complete maintenance treatment, allowing us to detect a difference between sucralfate and placebo maintenance treatment of $27-30 \%$ with the same degree of probability.

Recurrences were defined as symptomatic (symptoms with endoscopically-confirmed ulcer) or asymptomatic (no symptoms but endoscopically-confirmed ulcer). Recurrence rates were assessed by lifetable analysis according to the method of Cutler and Ederer ${ }^{39}$ with time to response grouped into 30 day intervals. Lifetable curves for sucralfate and placebo were compared with the generalised Kruskal-Wallis test by Breslow..$^{40}$ In addition, cumulative relapse rates based on the patients at risk after six and 12 months were calculated (descriptive statistics). For the analysis of risk factors the Cox proportional hazards regression model was used. ${ }^{+1}$

\section{Results}

The results of the initial ulcer treatment trial have been published elsewhere. ${ }^{37}$ Briefly, 160 patients were admitted to the study. After the exclusion of four patients with carcinoma, 10 patients with pyloric ulceration, two patients with other protocol violations, five patients with intercurrent diseases, and five patients because of lack of compliance, a total of 134 patients could be analysed. Healing after six weeks was observed in 37 of 66 patients $(56 \%)$ who had been treated with sucralfate and 49 of 68 patients $(72 \%)$ who had been treated with ranitidine. The cumulative healing rates after 12 weeks were $82 \%$ and $88 \%$, respectively. The differences between the two types of treatment were not significant after six and 12 weeks.

Of the 109 patients with healed ulcer $(51$ of 62 patients treated with sucralfate and 58 of 66 treated with ranitidine), 92 agreed to enter the maintenance treatment trial. All 17 patients who refused gave as a reason their unwillingness to come to regular control visits and to undergo
TABLE II Premature withdrawals from the study

\begin{tabular}{|c|c|c|}
\hline & \multicolumn{2}{|c|}{ Maintenance treatment } \\
\hline & Sucralfate & Placebo \\
\hline No of patients admitted & 49 & 42 \\
\hline $\begin{array}{l}\text { Reasons for withdrawal: } \\
\text { Epigastric pain, but no }\end{array}$ & & \\
\hline $\begin{array}{l}\text { Epigastric pain, but no } \\
\text { endoscopic recurrence }\end{array}$ & 0 & 1 \\
\hline Suspected side effects & $1^{\star}$ & $1+$ \\
\hline Intercurrent diseases & $2 \ddagger$ & 25 \\
\hline Lack of compliance & $12^{\top}$ & 8 \\
\hline Total No of withdrawals & 15 & 12 \\
\hline
\end{tabular}

*Obstipation. †Postprandial fullness. $¥$ Cardiac insufficiency malignancy. \$Myocardial infarction in both patients.

compulsory endoscopy after one year of maintenance treatment. Of the 92 patients included in the trial, one patient later withdrew his consent and demanded that his data be withdrawn from the data analysis. Details of the remaining 91 patients are shown in Table I. The patient characteristics are well matched in both the sucralfate and the placebo maintenance treatment groups. Table II shows the reasons patients were withdrawn from the study: none had an ulcer recurrence at the time of withdrawal. Of the 20 patients subsequently withdrawn for lack of compliance, five had moved to another town and thus changed their physician, 14 were asymptomatic and felt that there was no need to continue maintenance treatment, and one refused endoscopy after 12 months.

The Figure shows lifetable curves of symptom recurrence. Lifetable analysis of the entire 12 month observation period using Breslow's test showed a difference between placebo and sucralfate maintenance treatment with respect to both symptom recurrence alone $(p=0.044$, Figure) and total (symptomatic plus asymptomatic) recurrences $(p=0.039)$ (not shown separately). The difference for symptom recurrence was also significant when only the first six months of the maintenance trial were examined $(p=0.018)$.

At 12 months, $35(53 \%)$ of the 66 patients at risk had developed a recurrent ulcer: $15(43 \%)$ of 35 patients in the sucralfate group and $20(65 \%)$ of 31 patients in the placebo group.

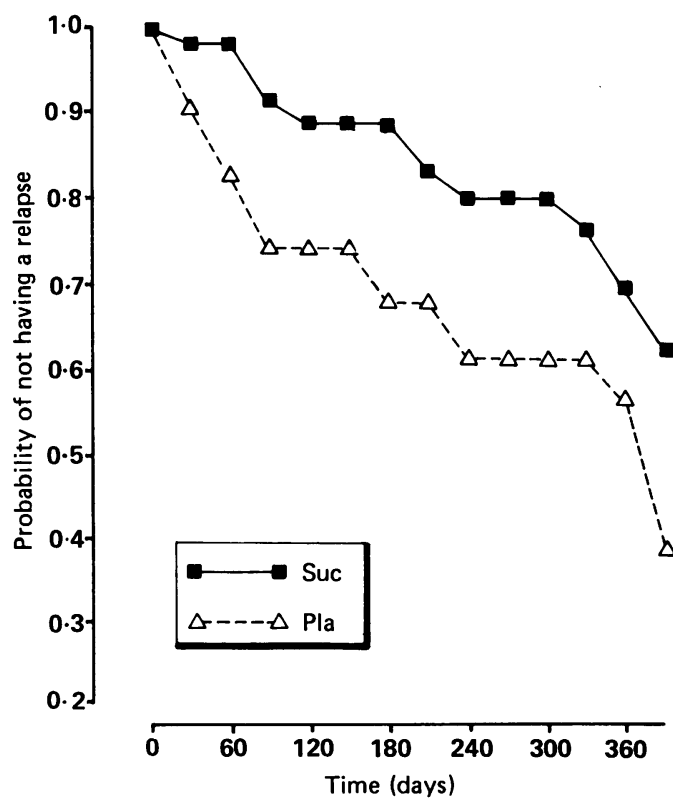

Lifetable curves of symptom recurrence in patients receiving maintenance treatment with sucralfate (Suc) or placebo (Pla). 
A total of 17 (23\%) symptom recurrences among the 74 patients at risk were observed in the first six months, and 12 further symptom recurrences were seen during the subsequent six months (Table III). Thus, the cumulative symptom recurrence rate in the 66 patients at risk was $44 \%$ in one year. The rates of symptom recurrence in sucralfate treated patients and placebo treated patients were $13 \%$ and $34 \%$ after six months and $34 \%$ and $55 \%$ after 12 months, respectively. Of the 37 patients who completed the 12 month trial without recurrent ulcer symptoms, six (16\%) were found to have had an asymptomatic recurrence.

Compliance during the study was excellent. The patients were asked to bring all unused tablets to their outpatient appointments. The percentage of patients who had taken at least $90 \%$ of the tablets was $81 \%$ after two months, $85 \%$ after four months, $92 \%$ after six months, $85 \%$ after eight months, $93 \%$ after 10 months, and $89 \%$ after 12 months.

Adverse drug events are listed in Table II. In the two patients who stopped maintenance treatment for suspected adverse drug events a causal relation between the symptoms and the drug intake appeared unlikely.

An analysis of risk factors that might predict a recurrence during the one year observation period was performed in all 91 patients. The following patient characteristics, potentially indicative of a high recurrence rate, were introduced into the analysis: maintenance treatment with placebo (42 patients), scarring deformation and narrowing of the pylorus (12 patients) and antrum (10 patients), intake of non-steroidal

TABLE III Recurrences observed during maintenance treatment with sucralfate and placebo. The denomination is the number of patients at risk during the first six months and for the entire study period. (Percentages in parentheses)

\begin{tabular}{llll}
\hline & Sucralfate & Placebo & Total \\
\hline $\begin{array}{l}\text { No of patients admitted to } \\
\text { maintenance treatment }\end{array}$ & 49 & 42 & 91 \\
$\begin{array}{l}\text { No of symptom recurrences } \\
\text { in first 6 months (\%) }\end{array}$ & $5 / 39(13)$ & $12 / 35(34)$ & $17 / 74(23)$ \\
$\begin{array}{l}\text { No of symptom recurrences } \\
\text { in 12 months (\% cumulative) }\end{array}$ & $12 / 35(34)$ & $17 / 31(55)$ & $29 / 66(44)$ \\
$\begin{array}{l}\text { No of asymptomatic recurrences } \\
\text { after 12 months (\%) }\end{array}$ & $3 / 34(9)$ & $3 / 30(10)$ & $6 / 64(9)$ \\
\hline
\end{tabular}

TABLE IV Number of patients at risk and one year recurrence rates in the presence and absence of alleged 'risk factors'

\begin{tabular}{|c|c|c|c|c|c|}
\hline \multirow[b]{3}{*}{ 'Risk factor' } & \multicolumn{4}{|c|}{ Risk factors } & \multirow[b]{3}{*}{ p† } \\
\hline & \multicolumn{2}{|c|}{$\operatorname{Present}(n)$} & \multicolumn{2}{|c|}{$\operatorname{Absent}(n)$} & \\
\hline & At risk & Recurrences & At risk & Recurrences & \\
\hline Maintenance treatment with placebo & 42 & 20 & 49 & 15 & $0 \cdot 131$ \\
\hline \multicolumn{6}{|l|}{ Daily use/consumption of: } \\
\hline Cigarettes & 69 & 27 & 22 & 8 & 1 \\
\hline Coffee & 80 & 29 & 11 & 6 & $0 \cdot 324$ \\
\hline Alcohol & 59 & 25 & 32 & 10 & 0.369 \\
\hline Non-steroidal anti-inflammatory drugs ${ }^{\star}$ & 24 & 5 & 67 & 30 & 0.0508 \\
\hline \multicolumn{6}{|l|}{ Past history of: } \\
\hline Previous ulcer attacks & 66 & 30 & 25 & 5 & 0.031 \\
\hline Haemorrhage & 4 & 2 & 87 & 33 & 0.637 \\
\hline Stressful life events & 49 & 22 & 42 & 13 & $0 \cdot 20$ \\
\hline \multicolumn{6}{|l|}{ Endoscopy showing: } \\
\hline Large ulcer $\left(>70 \mathrm{~mm}^{2}\right)$ & 36 & 15 & 55 & 20 & 0.663 \\
\hline Scarring deformation of the antrum & 10 & 6 & 81 & 29 & $0 \cdot 175$ \\
\hline Scarring of the pylorus & 12 & 8 & 79 & 27 & 0.0529 \\
\hline Deep ulcer with raised edges & 12 & 5 & 79 & 30 & \\
\hline Antral ulcer & 26 & 10 & 65 & 25 & 1 \\
\hline
\end{tabular}

^Stopped before initial ulcer treatment; $\lceil$ Fisher's exact test (2-sided). anti-inflammatory drugs before entering the trial (24 patients), a deep ulcer with edges markedly raised above the general mucosal surface suggesting long lasting ulceration (12 patients), past history of bleeding ulcer (four patients), previous ulcer attacks (66 patients), regular daily consumption of coffee (80 patients) or alcohol (59 patients) or use of cigarettes (69 patients), stressful life events (49 patients), and a large ulcer (area $>$ group mean of $70 \mathrm{~mm}^{2}$ ) before initial ulcer treatment ( 55 patients).

Table IV shows the one year recurrence rates in the presence and absence of 'risk factors.' Patients with their first ulcer attack had fewer recurrences than patients with a past history of at least one recurrence. No non-steroidal antiinflammatory drug use and scarring deformation of the pylorus just reached significance as risk factors. Additional factors such as age, sex, and a past history of slow ulcer healing were not associated with a high recurrence rate.

The potential risk factors were also examined in a multiple stepwise regression analysis using the Cox proportional hazards regression model. ${ }^{41}$ This model takes into account the time of appearance of the recurrences. The type of maintenance treatment was also included in this analysis. Two factors appeared in the whole patient sample: deformation of the pylorus followed by not taking non-steroidal antiinflammatory drugs before treatment (in contrast to patients who took the drugs but stopped taking them when told that they were ulcerogenic).

Finally, the effect of risk factors was also examined using a jackknifing method. This checks the stability of the regression model and the internal consistency of the data. In a first step, 10 subsets were created; each subset was to contain approximately $90 \%$ of the entire sample of 91 patients. A random selection procedure was used. The 10 subsets thus created contained 84 , $82,78,84,85,88,83,82,81$, and 83 patients respectively. In these subsets the Cox model was again applied. In each of the 10 subsets scarring deformation and narrowing of the pylorus appeared as a factor associated with a high recurrence rate. In eight and four subsets, respectively, no consumption of non-steroidal anti-inflammatory drugs and placebo treatment after ulcer healing appeared as factors associated with a high recurrence rate.

\section{Discussion}

The main feature of this study was the double blind administration of both initial ulcer treatment and maintenance treatment with a randomisation plan extending from initiation of treatment to one year after healing. Initial ulcer treatment was given with one of two active drugs, sucralfate or ranitidine, which were shown to be equally effective in healing ulcers; after healing, maintenance treatment with either sucralfate or placebo was given.

In presenting the results of this study we have concentrated on the symptom recurrence rate since we adopted a policy of performing offschedule, diagnostic endoscopies for all symptoms, however trivial, that might have 
indicated ulcer recurrence; a routine endoscopy was performed only at the end of the 12 month maintenance period. This allowed us to define a hard end point for the determination of the recurrence rate; in contrast, the recurrence rate determined by regular, routine endoscopy would have been dependent on the interval between endoscopic examinations. Our approach also had the advantage of using a clinically realistic end point for the detection of ulcer recurrence; despite this, the overall recurrence rate in this study was, in fact, comparable to that reported in previous studies, without the need for regular follow up endoscopies.

Maintenance treatment with $2 \mathrm{~g}$ sucralfate per day in this study produced a lower rate of symptom recurrence than placebo. In a lifetable analysis differences between sucralfate and placebo were significant, both over the first six months and over the entire study period of 12 months. The rates of symptom recurrences observed with sucralfate and placebo were $13 \%$ and $34 \%$ after six months and $34 \%$ and $55 \%$ after 12 months, respectively. In contrast, the rate of asymptomatic recurrences at 12 months was similar in the two treatment groups $(9 \%$ and $10 \%$, respectively).

The symptom recurrence rate with placebo at one year (55\%) was higher in this study than in previous studies. In 12

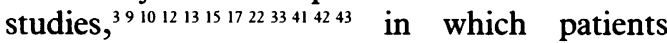
had been treated with placebo, the symptom recurrence rate at one year was $47 \%$ (104 recurrences in 221 patients). In eight studies, ${ }^{3-7}$ in which patients had been followed up off treatment, the one year symptom recurrence rate was $39 \%$ ( 231 recurrences in 586 patients). In contrast to symptom recurrences, the proportion of patients having asymptomatic recurrences was lower in our study $(17 \%$ of all recurrences) than in 13 published studies in which $77 \%(31 \%)$ of 245 recurrences were asymptomatic. ${ }^{911-14} 1516273435424477$ This difference may be explained in part by our offschedule endoscopies, which were performed even if only mild and atypical symptoms were present.

In all previous studies ${ }^{32-35}$ comparing sucralfate with placebo there was at least a trend in favour of sucralfate but a significant difference was reported by only one group of investigators and that only in studies lasting for six months. ${ }^{34} 35$ In other studies, sucralfate and histamine $\mathbf{H}_{2}$ receptor antagonists alone $\mathrm{e}^{20}{ }^{33}$ or in combination ${ }^{20}$ appeared to be equally effective. Overall, histamine antagonists such as cimetidine ${ }^{91013-1748}$ and ranitidine $e^{122223252643}$ appear to be superior to placebo in the prevention of gastric ulcer relapses but, as in the case of sucralfate, most studies were too small and the large studies ${ }^{11212849}$ were not controlled. The present study is one of the few trials of adequate size with treatment lasting up to one year to give a conclusive result regarding the prevention of gastric ulcer relapse with maintenance drug treatment.

We have also examined whether the recurrence rate can be predicted on the basis of a patient's characteristics evaluated before initial ulcer treatment. Patients with their first ulcer attack had fewer recurrences than patients with recurrent disease. The second factor of importance is the consumption of non-steroidal antiinflammatory drugs. The role of NSAIDs in the production of gastric ulcers and their recurrence is controversial..$^{950}$ In the present study, all patients who had been taking NSAIDs before the trial stopped taking them when told that they were ulcerogenic. These patients had a lower recurrence rate than patients who had never taken NSAIDs. This suggests that in these patients gastric ulcer development may be linked to NSAIDs and that they therefore do better, when the offending agent is withdrawn, than patients in whom the gastric ulcer developed because of other factors. Scarring deformation and narrowing of the pylorus also appeared to favour recurrence; this may be related to claims that gastric retention due to outlet obstruction may play a part in certain forms of gastric ulcer. ${ }^{5253}$ Like others, we found no increased recurrence rate in patients who consumed alcohol, ${ }^{51}$ in older patients, ${ }^{45051}$ in men, ${ }^{4505154}$ in smokers, ${ }^{94263450515455}$ or in patients with antral ulcers. ${ }^{53556}$ In contrast to others, we found no increased recurrence rate in patients with large ulcers $^{405456}$ nor in patients with slow ulcer healing. ${ }^{47+250} 51545758$

Compared with histamine $\mathrm{H}_{2}$ receptor antagonists, sucralfate has the theoretical advantage that it does not favour colonisation of the stomach with colonic flora ${ }^{59-61}$; it could be argued that long standing colonisation favours gastric cancer, particularly in patients with gastric ulcers and atrophic gastritis. ${ }^{61}$ Since maintenance treatment with either sucralfate or antisecretory agents reduces the recurrence rate of gastric ulcer, it would be of interest to perform maintenance trials of several years' duration, to study the social impact ${ }^{63}$ of such treatment, and to assess whether the theoretical advantages of sucralfate are clinically relevant.

Supported by Swiss National Fund Grant 3.827-0.86.

1 Dobrilla G, Vallaperta P, Amplatz S. Influence of ulcer healing agents on ulcer relapse after discontinuation of acute treatment: a pooled estimate of controlled clinical trials. $G u$ 1988; 29: 181-7.

2 Marks IN, Wright JP, Lucke W, Girdwood AH. Relapse rate after initial ulcer healing with sucralfate and cimetidine. Scand F Gastroenterol 1982; 17: 429-32.

3 Morgan AG, McAdam WAF, Pacsoo C, Darnborough A Comparison between cimetidine and Caved-S in the treatment of gastric ulceration, and subsequent maintenance ment of gastric ulceration, and
therapy. Gut 1982; 23: 545-51.

4 Miyake T, Ariyoshi J, Suzaki T, Oishi M, Sakai M, Ueda S Endoscopic evaluation of the effect of sucralfate therapy and other clinical parameters on the recurrence rate of gastric ulcer. Dig Dis Sci 1980; 25: 1-7.

5 Solhaug JH, Carling L, Glise $\dot{H}$, et al. Ulcer recurrence following initial ulcer healing with sucralfate or cimetidine. Scand F Gastroenterol 1987; 22 (suppl 127): 77-80.

6 Ström M, Gothard R, Bodemar G, Walan A. Antacid anticholinergic, cimetidine, and placebo in treatment of active peptic ulcers. Scand F Gastroenterol 1981; 16: 593 602 .

7 Sutton DR. Gastric ulcer healing with tripotassium dicitrato bismuthate and subsequent relapse. Gut 1982; 24: 621-4.

8 Tytgat GNJ, Van Bentem N, Van Olffen G, Dekker W, Rutgeerts L, De Boer J. Controlled trial comparing colloidal bismuth subcitrate tablets, cimetidine and placebo in the bismuth subcitrate tablets, cimetidine and placebo in the
treatment of gastric ulceration. Scand $\mathcal{F}$ Gastroenterol 1982 ; treatment of gastric

9 Barr GD, Kang JY, Canalese J, Piper DW. A two-year prospective controlled study of maintenance cimetidine and gastric ulcer. Gastroenterology 1983; 85: 100-4.

10 Birger Jensen K, Møllmann DM, Rahbek I, Rask Madsen J, Rune SJ, Wulff HR. Prophylactic effect of cimetidine in gastric ulcer patients. Scand f Gastroenterol 1979; 14: 175-6.

11 Boyd EJS, Wilson JA, Wormsley KG. Maintenance treatment of duodenal and gastric ulcer with ranitidine. In: Riley AS Salmon PR, eds. Ranitidine. Proceedings of an Internationa Symposium held in the context of the 7 th World Congress of 
Gastroenterology. Stockholm June 1982. Amsterdam: Excerpta Medica, 1982: 102-16.

12 Cockel R, Dawson J, Jain S. Ranitidine in gastric ulceration. Scand $\mathcal{Y}$ Gastroenterol 1982; 17 (suppl 78): A155.

13 Danielsson A, Ek B, Steen L. Effect of fifteen months of double-blind treatment with cimetidine and placebo on peptic ulcer recurrence. Eurf Clin Pharmacol 1981; 19: 335 41 .

$14 \mathrm{Da}$ Silva EP, Zaterka S. Long-term treatment of gastric ulcer with cimetidine. Clin Ther 1981; 4: 24-31.

15 Hentschel E, Schütze K, Weiss W, et al. Effect of cimetidine treatment in the prevention of gastric ulcer relapse: a on year double blind multicentre study. Gut 1983; 24: 853-6.

16 La Brooy SJ, Taylor RH, Ayrton C, et al. Cimetidine in the maintenance treatment of gastric ulceration (GU). Hepatogastroenterology 1980; (suppl June): A205.

17 Machell RJ, Ciclitira PJ, Farthing MJG, Dick AP, Hunter JO Cimetidine in the prevention of gastric ulcer relapse. Postgrad Med F 1979; 55: 393-5.

18 Morgan AG, Pacsoo C, McAdam WAF. Maintenance therapy: a two year comparison between Caved-S and cimetidine treatment in the prevention of symptomatic gastric ulcer recurrence. Gut 1985; 26: 599-602.

19 Okabe $\mathrm{H}$, Inoue K, Okabe K, et al. A study of maintenance therapy with cimetidine on gastric ulcer relapse. Curr Ther Res 1987; 41: 478-91.

20 Takemoto T, Kimura K, Okita K, et al. Efficacy of sucralfate in the prevention of recurrence of peptic ulcer - double blind in the prevention of recurrence of peptic ulcer-double blind
multicentre study with cimetidine. Scand $\mathcal{F}$ Gastroenterol 1987; 22 (suppl 140): 49-60.

21 Walan A, Bianchi-Porro G, Hentschel E, Bardhan KD, Delatrere $M$. Maintenance treatment with cimetidine in peptic ulcer disease for up to 4 years. Scand $\mathcal{F}$ Gastroenterol 1987; 22: 397-405.

22 Alstead EM, Ryan FP, Holdsworth CD, Ashton MG, Moore $M$. Ranitidine in the prevention of gastric and duodenal ulcer relapse. Gut 1983; 24: 418-20.

23 Dawson J, Jain S, Cockel R. Effect of ranitidine and cimetidine on gastric ulcer healing and recurrence. Scand $\mathcal{f}$ Gastroenterol 1984; 19: 665-8.

24 Gibinski K, Nowak A, Gabryelewicz A, et al. Ranitidine in the maintenance therapy of gastro-duodenal ulcer disease: maintenance therapy of gastro-duodenal ulcer disease:
Polish open multicentre study. Hepatogastroenterology 1984; 31: $180-2$.

25 Hellier MD, Gent AE, Walker J, Britten D, Hutchison C, Cough KR. Ranitidine in the treatment of gastric ulcers: healing and maintenance. Scand $\mathcal{F}$ Gastroenterol 1982; 17 (suppl 78): 134 .

26 Jorde R, Burhol PG, Hansen T. Ranitidine $150 \mathrm{mg}$ at night in the prevention of gastric ulcer relapse. Gut $1987 ; 28: 460-3$.

27 Picciotto A, Canepa A, Gismindi C, Dodero M, Celle G. Ranitidina e recidive dell'ulcera peptica, duodenale e gastrica: studio aperto a lungo termine. Osservazioni preliminari. In: Barbara L, Dobrilla G, eds. Problemi di Gastroenterologia e Ranitidina. Verona: Libreria Cortina, 1984: 387-91.

28 Rohner HG. Long term cimetidine therapy for the prevention of recurring peptic ulcer: a multicentre study. Z Gastroenterol 1985; 23: 403-11.

29 Bianchi Porro G, Dal Monte PR, Lazzaroni M, Petrillo M, D'Imperio N, Imbimbo BP. Pirenzepine and ranitidine for chronic gastric ulcer: a comparison in short-term and maintenance treatment. Curr Ther Res 1986; 39: 149-55.

30 Bianchi Porro G, Petrillo M. A controlled trial comparing cimetidine with carbenoxolone sodium in gastric ulcer (short and long-term study). Drugs Exp Clin Res 1979; 5: 173-6.

31 Búzás G, Puscas I, Milas D, Valean S. Maintenance therapy with carbonic anhydrase inhibitors in the prevention of gastric and

32 Classen M, Bethge H, Brunner G, et al. Effect of sucralfate on peptic ulcer recurrence: a controlled double-blind multicentre study. Scand $\mathcal{F}$ Gastroenterol 1983; 18 (suppl 83); centre

33 Jean F, Bonnefond A, Gislon J, et al. Traitement d'entretien de la maladie ulcéreuse: étude multicentrique comparative du sucralfate, de la cimétidine et d'un placebo. Rev Méd Interne 1985; 6: 321-6.

34 Marks IN, Wright JP, Girdwood AH, Gilinsky NH, Lucke $\mathrm{W}$. Maintenance therapy with sucralfate reduces rate of gastric ulcer recurrence. Am $\mathcal{F}$ Med 1985; 79 (suppl 2C): 32-5.

35 Marks IH, Girdwood AH, Wright JP, et al. Nocturnal dosage regimen of sucralfate in maintenance treatment of gastric ulcer. Am F Med 1987; 83 (suppl 3B): 95-8.

36 Libeskind $\mathrm{M}$. Maintenance treatment of patients with healed peptic ulcer with sucralfate, placebo and cimetidine. Scand $\mathcal{f}$ peptic ulcer with sucralfate, placebo and
Gastroenterol 1983; 18 (suppl 83): 69-70.
37 Blum AL, Bode JCh, Domschke W, et al. Therapie des Ulcus ventriculi mit Sucralfat und Ranitidin: eine multizentrische Doppelblindstudie. Dtsch Med Wochenschr 1986; 111: 1910-5.

38 Pace F, Bröcker HJ, Caspary W, et al. Therapie des Ulcus ventriculi mit niedrig dosiertem Antacidumgel und Cimetidin. Dtsch Med Wochenschr 1985; 110: 283-7.

39 Cutler SJ, Ederer F. Maximum utilization of the life table method in analyzing survival. $\mathcal{F}$ Chronic Dis 1958; 8: 699712 .

40 Breslow N. A generalized Kruskal-Wallis test for comparing $\mathrm{K}$ samples subject to unequal patterns of censorship. Biometrika 1970; 57: 579-94.

41 Cox DR. Regression models and life-tables. $\mathcal{F} R$ Statistical Soc 1972; 34: 187-220.

42 Jorde R, Bostad L, Burhol PG. Asymptomatic gastric ulcer: a follow-up study in patients with previous gastric ulcer disease. Lancet 1986; i: 119-21.

43 Liedberg G, Davies HJ, Enskog L, et al. Ulcer healing and relapse prevention by ranitidine in peptic ulcer disease. Scand f Gastroenterol 1985; 20: 941-4.

44 Hallerbäck B, Solhaug JH, Carling L, et al. Recurrent ulcer after treatment with cimetidine or sucralfate. Scand $\mathcal{F}$ Gastroenterol 1987; 22: 791-7.

45 Lee FI, Samloff IM, Hardman M. Comparison of tripotassium di-citrato bismuthate tablets with ranitidine in healing and relapse of duodenal ulcers. Lancet 1985; i: 1299 302 .

46 Manniche C, Malchow-Møller A, Andersen JR, et al. Randomised study of the influence of non-steroidal antiinflammatory drugs on the treatment of peptic ulcer in patients with rheumatic disease. Gut 1987; 28: 226-9.

47 Anglo-Irish Long Term Cimetidine Study Group. Prophylaxis against duodenal (DU) and gastruc ulcer (GU) recurrence using maintenance treatment $(\mathrm{MT})$ with cimetidine $(\mathrm{C})$ : 4-year results. Gastroenterology 1985; 88: A1307.

48 Bodemar G, Walan A. Maintenance treatment of recurrent peptic ulcer by cimetidine. Lancet 1978; i: 403-7.

49 Record CO. Maintenance treatment with ranitidine in peptic ulceration. In: Tytgat GN, ed. Ranitidine, the selective new H2-receptor antagonist. Proceedings of Glaxo International Symposium Amsterdam 1982. Guildford: Theracom, 1982: $20-4$.

50 Piper DW, Greig M, Coupland GAE, Hobbin E, Shinners J. Factors relevant to the prognosis of chronic gastric ulcer. Gut 1975; 16: 714-8.

51 Piper DW, Shinners J, Greig M, Thomas J, Waller SL. Effect of ulcer healing on the prognosis of chronic gastric ulcer. Gut 1978; 19: 419-24.

52 Liebermann-Meffert D, Allgöwer M. The morphology of the antrum and pylorus in gastric ulcer disease. Prog Surg 1977; 15: 109-39.

53 Dragstedt LL, Woodward ER. Gastric stasis: a cause of gastric ulcer. Scand f Gastroenterol 1970; 5: 243-52.

54 Morgan AG, McAdam WAF, Pacsoo C, Walker BE, Simmons AV. Cimetidine: an advance in gastric ulcer treatment? $\mathrm{Br}$ Med F 1978; ii: 1323-6.

55 Tatsuta M, Iishi H, Okuda S. Effects of cigarette smoking on the location, healing and recurrence of gastric ulcers. the location, healing and recurrence
Hepatogastroenterology 1987; 34: 223-8

56 Alp MH, Hislop IG, Grant AK. The influence of site on the natural history of gastric ulceration. Surg Gynecol Obstet 1972; 134: 470-2.

57 Thomas J, Greig M, McIntosh J, Hunt J, McNeil D, Piper DW. The location of chronic gastric ulcer. A study of the relevance of ulcer size, age, sex, alcohol, analgesic intake and smoking. Digestion 1980; 20: 79-84.

58 Hanscom DH, Buchman E. The follow-up period. Gastroenterology 1971; 61: 585-91.

59 Daschner F, Reuschenbach K, Pfisterer J, et al. Der Einfluss von Stressulcusprophylae auf die Häufigkeit einer

60 Driks MR, Craven DE, Celli DR, et al. Nosocomial pneumonia in intubated patients given sucralfate as pneumona in intubated patients given sucralfate as
compared with antacids of histamine type 2 blockers. $N E$ Egl compared with antacids of

61 Meyrick Thomas J, Misiewicz JJ, Cook AR, et al. Effect of one year's treatment with ranitidine and of truncal vagotomy on gastric contents. Gut 1987; 28: 726-38.

62 Sipponen $P$, Kekki $M$, Siurala $M$. Age-related trends of gastritis and intestinal metaplasia in gastric carcinoma patients and in controls representing the population at large. Brf Cancer 1984; 49: 521-30.

63 Piper DW, Pym BM, Toy S, Gellatly R, Byth K, Seville P. The effect of maintenance cimetidine therapy on the medical, social and economic aspects of patients with chronic gastric ulcers. A placebo-controlled prospective chronic gastric ulcers. A placebo-
study. Med F A ust 1986; 145: 400-3. 